\title{
Effect of one-time dextran-polyacrylamide polymer matrixes treatment on female reproductive function
}

\author{
Valentyna A. Sribna', Oksana N. Kaleinikova1 ${ }^{1}$, Yulia I. Kuziv ${ }^{2}$, Alena A. Vinogradova Anyk ${ }^{3}$, \\ Igor N. Karvatskiy ${ }^{3}$, Tetiana Y. Voznesenskaya ${ }^{1}$, Taras V. Blashkiv ${ }^{1 *}$, Natalia V. Kutsevol ${ }^{2}$
}

\begin{abstract}
${ }^{1}$ Department of Immunophysiology, Bogomoletz Institute of Physiology, NAS of Ukraine, Kyiv, Ukraine
${ }^{2}$ Department of Chemistry, Taras Shevchenko National University of Kyiv, Kyiv, Ukraine

${ }^{3}$ Department of Physiology, Bogomoletz National Medical University, Kyiv, Ukraine
\end{abstract}

Received: 21 March 2020

Accepted: 22 April 2020

\author{
*Correspondence: \\ Dr. Taras V. Blashkiv, \\ E-mail: tblashkiv@gmail.com
}

Copyright: ( ) the author(s), publisher and licensee Medip Academy. This is an open-access article distributed under the terms of the Creative Commons Attribution Non-Commercial License, which permits unrestricted non-commercial use, distribution, and reproduction in any medium, provided the original work is properly cited.

\section{ABSTRACT}

Background: recently, it has been proved that copolymers with dextran cores and grafted polyacrylamide are effective in photodynamic and chemotherapy. However, further research is needed to define correct dosage and to assess the risks. Thus, animal studies are becoming more relevant to determine the effect of the treatment of such drug nano-systems on female reproductive function in particular.

Methods: a technique for estimation of pre- and post-implantation death rates, in vitro meotic maturation of oocytes, double fluorescent vital assay and statistical analysis were used. The effects of a one-time treatment of different doses of dextran-polyacrylamide matrices and silver (Ag)-nanoparticles-dextran-polyacrylamide (AgNPs-D-PAA) on reproductive function, namely on 1) the number of oocytes isolated from one ovary and the meiotic maturation of such oocytes in vitro; 2) the indicators of cell viability of the cells of follicular environment of oocytes (FEO) and the cells of inguinal lymph nodes (ILN); 3) the pre- and post-implantation mortality rates and the number of live newborns (pups) were investigated in female mice.

Results: no significant changes in the number of oocytes isolated from one ovary and meiotic maturation of such ovarian oocytes in vitro, the number of living cells of follicular environment of oocytes and the number of such cells with morphological signs of apoptosis and necrosis, pre- and post-implantation mortality rates of embryos and the number of live newborns (pups) have been established under conditions of one-time treatment with dextranpolyacrylamide at doses of $0.39 \mathrm{mg} / \mathrm{kg}$ and $3.90 \mathrm{mg} / \mathrm{kg}$ and $\mathrm{Ag}$-nanoparticles-dextran-polyacrylamide at doses of 0.20 $\mathrm{mg} / \mathrm{kg}$ and $2.00 \mathrm{mg} / \mathrm{kg}$.

Conclusions: branched polymer systems (dextran-polyacrylamide (D-PAA) polymer matrices) are promising materials for use in next-generation medicine.

Keywords: Apoptosis, Dextran-polyacrylamide polymers, Meiotic maturation of oocytes, Necrosis, Pre- and postimplantation mortality

\section{INTRODUCTION}

Nowadays, the use of nanotechnology to create new highperformance biomedical nanocomposites proves to be one of the most relevant research topics. Due to the structural features and manage ability of the intramolecular structure, branched polymer systems are interesting objects of basic research as well as promising functional materials of the new generation. Such polymer systems are characterized by a more compact structure and, therefore, a higher concentration of functional groups compared to linear analogs of close molecular weight.

Recently, it has been proved that polymers with a dextran core and grafted polyacrylamide chains dextran- 
polyacrylamide (D-PAA) are effective in photodynamic chemotherapy, which gives confidence in the prospect of drug-nanosystem. ${ }^{1,2}$

However, further research is needed to turn the concept of nanotechnology into practical application, to define correct dosage and the optimal internal structure of the polymer for the ideal release of a therapeutic agent encapsulated in a polymer molecule, and to assess the risks (side effects, contraindications).

Thus, animal studies are becoming more relevant to determine the effect of the treatment of such drug nanosystems (D-PAA polymer matrices) on female reproductive function in particular.

This study aims to evaluate the effect of a one-time treatment of different doses of D-PAA polymer matrices and Ag-nanoparticles-dextran-polyacrylamide (AgNPsD-PAA) on reproductive function, namely on 1) the number of oocytes isolated from one ovary and the meiotic maturation of such oocytes in vitro; 2) the indicators of cell viability of the cells of follicular environment of oocytes (FEO) and the cells of inguinal lymph nodes (ILN); 3) the pre- and post-implantation mortality rates and the number of live new-borns (pups) in female mice.

\section{METHODS}

Characteristics of polymer matrices: "uncharged" starlike polymeric matrices D-PAA consist of a dextran core and grafted polyacrylamide chains. Hydrodynamic dimensions of macromolecules are 70-80 nm (Table 1).

The star-like polymer matrixes D-PAA were loaded with silver nanoparticles (AgNPs-D-PAA). The size of such silver nanoparticles is 8-15 $\mathrm{nm}$. Details of synthesis, identification and analysis of the internal polymeric structure have been described before. ${ }^{3,4}$

Animals. Experiments (two series) have been conducted on 55 females and 10 male white laboratory mice (weighing 20-22 g) in compliance with all requirements for work with laboratory animals (International European Convention for the Protection of Vertebrate Animals, Strasbourg, 1986). After the experiments, anesthetized by Nembutal animals were exterminated by cutting the spinal cord. The objective status of the animals (appearance, overall motor activity, need for food and water, and body weight) were evaluated before and during the experiment.

In the first series of experiments, animals were divided into the following groups: I - control animals treated with physiological solution $(0.3 \mathrm{~mL})(\mathrm{N}=5)$; II - animals under condition on treatment of D-PAA at a dose of $0.39 \mathrm{mg} / \mathrm{kg}$ $(\mathrm{N}=5)$; III - animals under condition on treatment of DPAA at a dose of $3.90 \mathrm{mg} / \mathrm{kg}(\mathrm{N}=5)$; IV - animals under condition on treatment of AgNPs-D-PAA at a dose of
$0,20 \mathrm{mg} / \mathrm{kg}(\mathrm{N}=5) ; \mathrm{V}$ - animals under condition on treatment of AgNPs-D-PAA at a dose of $2.00 \mathrm{mg} / \mathrm{kg}$ $(\mathrm{N}=5) ; \mathrm{N}$ is the number of animals in the group. The sampling of the experimental material (ovaries and ILN) was performed under anesthetic anesthesia the day after administration. The animals were removed from the experiment by cutting the spinal cord under anesthetic anesthesia, following the rules of euthanasia.

In the second series of experiments, animals were divided into the same groups: I - control animals treated with physiological solution $(0,3 \mathrm{~mL})(\mathrm{N}=6)$; II - animals under condition on treatment of D-PAA at a dose of $0,39 \mathrm{mg} / \mathrm{kg}$ $(\mathrm{N}=6)$; III - animals under condition on treatment of $\mathrm{D}$ PAA at a dose of $3,90 \mathrm{mg} / \mathrm{kg}(\mathrm{N}=6) ; \mathrm{IV}$ - animals under condition on treatment of AgNPs-D-PAA at a dose of $0,20 \mathrm{mg} / \mathrm{kg}(\mathrm{N}=6) ; \mathrm{V}$ - animals under condition on treatment of AgNPs-D-PAA at a dose of $2,00 \mathrm{mg} / \mathrm{kg}$ $(\mathrm{N}=6) ; \mathrm{N}$ is the number of animals in the group.

On the third day after the treatment, males were planted to the females in a ratio of 1:3. Coupling and subsequent manipulation of embryos were performed according to the method by Mank, 1990. Sampling of experimental material (ovaries, tubes, and uterus) was performed under anesthetic anesthesia for 10/11 days after replanting.

The experiment was completed on day 24 after replanting the male with birth in control and experimental animals' live newborns (pups).

The treatment of substances was carried out in the following way: D-PAA, AgNPs-D-PAA, physiological solution was introduced intravenously (in the tail vein) once a day.

Oocytes cultivation. The oocytes were mechanically isolated from the ovaries of mice in a non-enzymatic way (without cumulus cells) and units/one ovaries (pieces on one ovary) were counted. Then oocytes from one group were collected and distributed into separate chambers 1020 oocytes each. All control and experimental oocytes were cultured under the same conditions (a sterile box, cameras with $0.4 \mathrm{ml}$ culture medium DME and $15 \mathrm{mM}$ HEPES, $\mathrm{Ca}^{2}+$ concentration of $1.71 \mathrm{mM}$, temperature $37^{\circ} \mathrm{C}$, duration 20 hours). Morphological study of oocytes was performed under a microscope MBS-10 after 2 hours of cultivation (\% of total): the oocytes which restored the meiotic maturation (resumption meiosis) and were at metaphase I stage (germinal vesicle break-down) and after 20 hours of cultivation oocytes with the first polar body (were at metaphase II stage) and oocytes with atypical morphology (unevenly granulated cytoplasm and fragmentation characteristics of the latter) were counted.

Method of color fluorescent dyes. The apoptotic and necrotic death of FEO cells and cells of ILN was estimated by morphological characteristics using the method of in vivo dual-color fluorescent dye nucleic acids Hoechst 33342 and propidium iodide. ${ }^{5}$ At least 400 
cells were evaluated using a fluorescence microscope LUAMAM I-1 (Russia) with an x85 water-immersion lens. Embryonic mortality in mice. The pre- and postimplantation death rates were calculated by the formulas: $[(\mathrm{C}-\mathrm{A}+\mathrm{B}) / \mathrm{C}] \cdot 100 \%$ and $[\mathrm{B} /(\mathrm{A}+\mathrm{B})] \cdot 100 \%$, respectively.

Counted: A - the number of live embryos, B - the number of sites of resorption (the number of dead embryos), C the number of yellow bodies of pregnancy.

\section{Statistical analysis}

For the statistical analysis of the results the software package graph pad prism version 5.00 for windows (graph pad software, San Diego California, USA) have been used.

The verification of the received data on normality of distribution was carried out on the Kolmogorov-Smirnov test. For a normal distribution, the statistical processing of the results when comparing the two data groups was performed using Student's t-test, with more data groups using a single-factor ANOVA analysis, followed by a comparison of mean values between the groups according to the Newman-Keuls post hoc test; $\mathrm{p}<0.05$ was considered statistically significant.

\section{RESULTS}

Effect of one-time treatment with D-PAA and AgNPs-DPAA on number of oocytes isolated from one ovary. No significant changes in the number of oocytes isolated from one ovary were established under conditions of DPAA treatment $(0.39 \mathrm{mg} / \mathrm{kg}$ and $3.90 \mathrm{mg} / \mathrm{kg})$, respectively, $13.17 \pm 0.31$ and $12.88 \pm 0.35$ pieces, as well as AgNPs-D-PAA $(0,20 \mathrm{mg} / \mathrm{kg}$ and $2,00 \mathrm{mg} / \mathrm{kg})$, respectively, $12.72 \pm 0.41$ and $12.34 \pm 0.43$ pieces compared with such values in the control $13.57 \pm 0.57$ pieces.

Table 1: Characteristics of D-PAA polymer matrices.

\begin{tabular}{|llll|l|}
\hline Sample & $\begin{array}{l}\mathbf{M}_{\mathrm{w}} \bullet \mathbf{1 0}^{-6}, \\
\mathrm{~g} / \mathbf{M}\end{array}$ & $\begin{array}{l}\mathbf{R}_{\mathrm{g}}, \\
\mathbf{n m}\end{array}$ & $\mathbf{M}_{\mathrm{w}} / \mathbf{M}_{\mathbf{n}}$ & $\begin{array}{l}\left(\mathbf{R}_{\mathrm{g}}{ }^{2} / \mathbf{M}_{\mathrm{w}}\right) \bullet 10^{3}, \\
\mathbf{n m}^{2} \bullet \mathbf{M} / \mathbf{g}\end{array}$ \\
\hline D-PAA & 1.43 & 64 & 1.98 & 2.85 \\
\hline
\end{tabular}

Notes: $\mathrm{M}_{\mathrm{w}}$ is the average molecular weight; $\mathrm{R}_{\mathrm{g}}$ is the radius of inertia; $\mathrm{M}_{\mathrm{w}} / \mathrm{M}_{\mathrm{n}}$ is the degree of dispersion field, $\mathrm{Rg}_{\mathrm{g}}{ }^{2} / \mathrm{M}_{\mathrm{w}}$ is compactness factor.

Effect of one-time treatment with D-PAA and AgNPs-DPAA on oocytes meiotic maturation in vitro. No significant changes in in vitro meiotic maturation of oocytes were established under conditions of D-PAA treatment $(0.39 \mathrm{mg} / \mathrm{kg}$ and $3.90 \mathrm{mg} / \mathrm{kg})$, respectively, resumed meiosis: $77.71 \pm 2.13 \%$ and $79.24 \pm 1.43 \%$; formed first polar body: $57.09 \pm 0.58 \%$ and $60.05 \pm 2.37 \%$, as well as AgNPs-D-PAA $(0.20 \mathrm{mg} / \mathrm{kg}$ and $2.00 \mathrm{mg} / \mathrm{kg}$ ), respectively, resumed meiosis: $81.11 \pm 2.14 \%$ and $75.25 \pm 3.24 \%$, formed first polar body: $62.40 \pm 0.73 \%$ and $60.62 \pm 3.12 \%$ compared with such values in the control $81.05 \pm 1.06 \%$ and $60.98 \pm 1.31 \%$. Effect of one-time treatment with D-PAA and AgNPs-D-PAA on cells of FEO. Data about the number of cells of FEO with morphological signs of apoptosis and necrosis under conditions of one-time treatment with D-PAA and AgNP/D-PAA are presented in Table 2.

Table 2: The number of cells of FEO with morphological signs of apoptosis and necrosis under conditions of onetime treatment with D-PAA and AgNPs-D-PAA.

\begin{tabular}{|lllll|}
\hline Group of animals & $\begin{array}{l}\text { Dose D-PAA and AgNPs-D- } \\
\text { PAA mg/kg }\end{array}$ & \multicolumn{2}{l}{ The number of cells of FEO, \% } & Living \\
\hline Control & - & $89.19 \pm 1.62$ & $8.44 \pm 1.21$ & Necrotic \\
\hline D-PAA & 0.39 & $86.75 \pm 1.21$ & $9.83 \pm 1.29$ & $3.38 \pm 0.88$ \\
\hline D-PAA & 3.90 & $86.92 \pm 1.50$ & $9.25 \pm 1.29$ & $3.83 \pm 0.58$ \\
\hline AgNPs-D-PAA & 0.20 & $87.58 \pm 1.56$ & $8.58 \pm 0.97$ & $3.83 \pm 0.93$ \\
\hline AgNPs-D-PAA & 2.00 & $82.33 \pm 1.54$ & $14.08 \pm 1.24$ & $3.58 \pm 0.58$ \\
\hline
\end{tabular}

Table 3: The number of cells of ILN with morphological signs of apoptosis and necrosis under conditions of onetime treatment with D-PAA and AgNPs-D-PAA.

\begin{tabular}{|lllll|}
\hline Group of animals & $\begin{array}{l}\text { Dose D-PAA and AgNPs-D- } \\
\text { PAA } \mathbf{~ m g / k g}\end{array}$ & \multicolumn{2}{l}{ The number of cells of ILN. \% } \\
\hline Control & - & Living & Apoptotic & Necrotic \\
\hline D-PAA & 0.39 & $85.75 \pm 1.13$ & $10.75 \pm 1.22$ & $3.5 \pm 0.65$ \\
\hline D-PAA & 3.90 & $86.75 \pm 1.08$ & $9.67 \pm 1.17$ & $3.58 \pm 0.80$ \\
\hline AgNPs-D-PAA & 0.20 & $82.33 \pm 2.04$ & $12.42 \pm 1.32$ & $5.25 \pm 0.82$ \\
\hline AgNPs-D-PAA & 2.00 & $86.67 \pm 1.33$ & $9.25 \pm 0.82$ & $4.08 \pm 0.86$ \\
\hline
\end{tabular}

Note: ${ }^{*}$-p $<0.05$ - probability differences in the average group data with respect to these variables in the control group animals; \#$\mathrm{p}<0,05$ - to these variables in the group animals under conditions of $0.20 \mathrm{mg} / \mathrm{kg}$ AgNPs-D-PAA treatment. 
There have been received no significant changes in viability of cells of FEO under conditions of one-time treatment with D-PAA $(0.39 \mathrm{mg} / \mathrm{kg}$ and $3.90 \mathrm{mg} / \mathrm{kg})$ and AgNP/D-PAA $(0.20 \mathrm{mg} / \mathrm{kg}$ and $2.00 \mathrm{mg} / \mathrm{kg})$ compared with such values in control group.

Effect of one-time treatment with D-PAA and AgNPs-DPAA on ILN cells. Data about the number of cells of ILN with morphological signs of apoptosis and necrosis under conditions of one-time treatment with D-PAA and AgNPs-D-PAA are presented in Table 3.

There has been received a decrease in the number of living cells of ILN and an increase in the number of apoptotic cells under the conditions of one-time treatment with AgNPs-D-PAA (2.00 mg/kg), compared with the such values in control and under the conditions of treatment with AgNPs-D-PAA $(0.20 \mathrm{mg} / \mathrm{kg})$.

Effect of one-time treatment with D-PAA and AgNPs-DPAA on pre- and post-implantation embryonic mortality rates. No significant changes in pre- and postimplantation mortality rates of embryos were established under conditions of treatment of D-PAA at doses of 0,39 $\mathrm{mg} / \mathrm{kg}$ and $0.39 \mathrm{mg} / \mathrm{kg}$ and AgNPs-D-PAA at doses of $0.20 \mathrm{mg} / \mathrm{kg}$ and $2.00 \mathrm{mg} / \mathrm{kg}$, respectively, of preimplantation mortality: $7.36 \pm 0.24 \%$ and $8.16 \pm 0.81 \%$, as well as $8.64 \pm 0.82 \%$ and $8.23 \pm 0.87 \%$ and post implantation mortality: $4.82 \pm 0.58 \%$ and $4.63 \pm 0.48 \%$, as well as $5.63 \pm 0.54 \%$ and $5.77 \pm 0.87 \%$, compared with such values in control $8.76 \pm 0.74 \%$ and $5.38 \pm 0.37 \%$.

Number of live new-borns (pups) under conditions of treatment with D-PAA and AgNPs-D-PAA. No significant changes in the number of live pups were found under conditions of treatment with D-PAA at doses of $0.39 \mathrm{mg} / \mathrm{kg}$ and $0.39 \mathrm{mg} / \mathrm{kg}$ and AgNPs-D-PAA at doses of $0.20 \mathrm{mg} / \mathrm{kg}$ and $2.00 \mathrm{mg} / \mathrm{kg}$, respectively, $7.0 \pm 0.00 \mathrm{pcs}$ and $7.00 \pm 0.58 \mathrm{pcs} ; 7.33 \pm 0.33 \mathrm{pcs}$ and $6.67 \pm 0.33$ pcs, respectively, compared with such value in the control $6.67 \pm 0.33$ pcs.

\section{DISCUSSION}

Branched polymer systems with a branched brush-like structure of macromolecules can be used to synthesize "smart" materials whose properties change dramatically under the influence of external factors. Such polymers are used in the development of therapeutic drugs of prolonged action, as a nanocarriers or nanocontainers for the transport and release of water-soluble drugs or for the transport of DNA in genetic engineering.

Nanocarriers based on the branched copolymers D-PAA were synthesized, characterized and tested on phagocytic cells. It has been shown that these nanocarriers are actively captured by phagocytic cells and that they are not cytotoxic. The polymer nanocarriers loaded with cisplatin at different concentrations from 0.1 to 10.0 $\mathrm{mkg} / \mathrm{mL}$ provided a dose-dependent decrease in viability of chronic myelogenous leukemia and histiocytic lymphoma cells. The lowest percentage of viable cells has been observed for lymphoma cells $(22 \%)$. When the copolymers were conjugated to both nano silver and cisplatin, such a nano-system displayed less cytotoxic effect compared to the conjugates to dextranpolyacrylamide and cisplatin. ${ }^{1}$

Authors used the following doses of D-PAA polymer: $0.39 \mathrm{mg} / \mathrm{kg}$ and $3.90 \mathrm{mg} / \mathrm{kg}$. It has been accepted that a dose of $10 \mathrm{mg} / \mathrm{kg}$ body weight in mice is equivalent to a human dose of $0.81 \mathrm{mg} / \mathrm{kg}$ body weight, equivalent to about $50 \mathrm{mg}$ for humans $60 \mathrm{~kg}$, according to the principles of conversion of doses of animals to humans.6 Following this rule $3.90 \mathrm{mg} / \mathrm{kg}$ D-PAA in mice is equivalent to a human dose of $0.3159 \mathrm{mg} / \mathrm{kg}$ body weight, equivalent to approximately $20 \mathrm{mg}(18.954 \mathrm{mg})$ for humans $60 \mathrm{~kg}$ (or $22.113 \mathrm{mg}$ for humans $70 \mathrm{~kg}$ ) according to the principles of conversion of animal doses to humans. ${ }^{6}$

In this work under conditions of one-time treatment with D-PAA at doses of $0.39 \mathrm{mg} / \mathrm{kg}$ and $3.90 \mathrm{mg} / \mathrm{kg}$ we have obtained no significant changes in the number of oocytes isolated from one ovary and meiotic maturation of such oocytes in vitro, the number of living cells of FEO and the number of such cells with morphological signs of apoptosis and necrosis, the viability of ILN cells, pre- and post-implantation mortality rates of embryos and the number of live newborns (pups).

As mentioned above, dextran-polyacrylamide polymer matrixes were loaded with silver nanoparticles (AgNPsD-PAA). The size of such silver nanoparticles is 8-15 $\mathrm{nm}$. This was done according to the techniques given in. ${ }^{3,4}$ Previously, we were used nanoparticles AgNPs - 30 $\mathrm{nm}$ (spherical, synthesized at the Ovcharenko Institute of biocolloidal chemistry NAS of Ukraine according to the original protocol (by chemical condensation). And it was shown that the ten-time AgNPs treatment $(2 \mathrm{mg} / \mathrm{kg}$ and 4 $\mathrm{mg} / \mathrm{kg}$ ) results in inhibition of oocytes meiotic maturation in mice; a single- and five-time AgNPs treatment (2 $\mathrm{mg} / \mathrm{kg}$ and $4 \mathrm{mg} / \mathrm{kg}$ ) increases the number of apoptotic cells, while the ten-time AgNPs treatment results in an increase of the apoptotic and necrotic follicular cells surrounding oocytes. ${ }^{7}$ Also we received data that under conditions of ten-time administration of AgNPs $(20 \mathrm{mg}$ $\mathrm{kg}$ ), the inhibition of reproductive function in female females is observed: a decrease in the number and quality oocytes was established, but the reproductive function in experimental animals was restored 37 days after the last administration of AgNPs and there were no differences between the values of pre- and post-implantation mortality of embryos on the $33 / 34^{\text {th }}$ day after male planting. ${ }^{8}$

Since authors had previously used a dose of AgNPs (2 $\mathrm{mg} / \mathrm{kg}$ ), this time again we applied the same $2 \mathrm{mg} / \mathrm{kg}$ and 10 times smaller dose $0.20 \mathrm{mg} / \mathrm{kg}$ of AgNPs that were 
loaded into the respective polymer matrixes (D-PAA) at doses of $0.39 \mathrm{mg} / \mathrm{kg}$ and $3.90 \mathrm{mg} / \mathrm{kg}$, respectively.

Under conditions of one-time treatment with AgNPs-DPAA at doses of $0.20 \mathrm{mg} / \mathrm{kg}$ and $2.0 \mathrm{mg} / \mathrm{kg}$ it was obtained no significant changes in the number of oocytes isolated from one ovary and meiotic maturation of oocytes in vitro, the number of living cells of FEO and the number of such cells with morphological signs of apoptosis and necrosis, pre- and post-implantation mortality rates of embryos and the number of live newborns (pups). Under conditions of one-time treatment with AgNPs-D-PAA at $2.0 \mathrm{mg} / \mathrm{kg}$ the viability of ILN cells was decresed: the number of living cells of FEO decreased by 1.12 times and the number of such cells with morphological signs of apoptosis increased by 1.56 times.

There is evidence that AgNPs influence the induction of oxidative damage, change the regulation of enzymes, which are responsible for removing free radicals, change regulation of genes expression, which are involved in apoptosis and disregulation of cellular structures involved in storage, detoxification and metabolism of metals in various organs. ${ }^{9,10}$ Silver ions were equally toxic as both metal particles containing $80 \%$ silver and pure AgNP indicating that at least their toxic potential was similar. ${ }^{11}$

Despite the fact that the toxicity appears to be caused by oxidation and inflammation. ${ }^{12-14}$ It is still not entirely clear what is responsible for the toxic effects of silver: whether this is the form of nanoparticles, or whether this is silver ions alone during oxidation of the metal. ${ }^{15,16}$

In this work, silver nanoparticles were used, which were loaded in a polymer container, so no toxic effect was expected from the such silver itself. Obtained data that AgNPs-D-PAA at doses of $2.00 \mathrm{mg} / \mathrm{kg}$ have a cytotoxic effect on cells of ILN that filter the reproductive (genital) zone in animals need to be explained in detail. More comprehensive studies are required in accordance with toxicological testing protocols.

Thus, authors would like to emphasize that the branched polymer systems (dextran-polyacrylamide (D-PAA) polymer matrices), due to their structural features and manageability of the intrinsic molecular structure, are and will remain interesting objects of basic research as well as promising functional materials of the new generation. The results described confirm the importance of parameters' estimation of reproductive function, which is a sensitive system for nanotechnology (nanotoxicology) related research.

Moreover, future research should focus on establishing the effect on female reproductive function depending on different multiplicity of D-PAA polymer matrices treatment (in particular, technically the maximum possible dose for such a D-PAA polymer matrices) and should expand on male reproductive function.

\section{CONCLUSION}

In this work we have obtained new data about the influence of star-like D-PAA and AgNPs-D-PAA on somatic, germinative cells, embryos and live new-borns (pups) in mammals, which had not previously been investigated: no significant changes in the number of oocytes isolated from one ovary and meiotic maturation of such ovarian oocytes in vitro, the number of living cells of FEO and the number of such cells with morphological signs of apoptosis and necrosis, pre- and post-implantation mortality rates of embryos and the number of live new-borns (pups) have been established under conditions of one-time treatment with D-PAA at doses of $0.39 \mathrm{mg} / \mathrm{kg}$ and $3.90 \mathrm{mg} / \mathrm{kg}$ and AgNPs-D-PAA at doses of $0.20 \mathrm{mg} / \mathrm{kg}$ and $2.00 \mathrm{mg} / \mathrm{kg}$. The branched polymer systems (dextran-polyacrylamide (D-PAA) polymer matrices) are promising materials for use in next-generation medicine.

\section{ACKNOWLEDGMENTS}

Authors would like to thank the Bogomoletz Instytute of Physiology NAS of Ukraine (Kyiv, Ukraine) for financially supported this study.

\section{Funding: No funding sources \\ Conflict of interest: None declared}

Ethical approval: The study was approved by Bogomoletz Instytute of Physiology Ethical Committee, Kyiv, Ukraine

\section{REFERENCES}

1. Telegeev G, Kutsevol N, Chumachenko V, Naumenko A, Telegeeva P, Filipchenko S, et al. Dextran-Polyacrylamide as Matrices for Creation of Anticancer Nanocomposite. Int J Polym Sci. 2017;1(9):1-9.

2. Kutsevol N, Naumenko A, Harahuts $\mathrm{Yu}$, Chumachenko V, Shton I, Shishko E, et al. New hybrid composites for photodynamic therapy: synthesis, characterization and biological study. Appl Nanosci. 2019;9(5):881-8.

3. Kutsevol N, Guenet J, Melnik N, Sarazin D, Rochas C. Solution properties of dextran-polyacrylamide graft copolymers. Polymer. 2006;47(6):2061-8.

4. Kutsevol N, Bezugla T, Bezuglyi M, Rawiso M. Branched dextran-graft-polyacrylamide copolymers as perspective materials for nanotechnology. Macromolecular Symposia. 2012;318(1):82-90.

5. Shimizu S, Eguchi Y, Kamiike W, Akao Y, Kosaka $\mathrm{H}$, Hasegawa $\mathrm{J}$, et al. Involvement of ICE family proteases in apoptosis induced by reoxygenation of hypoxic hepatocytes. Am J Physiol. 1996;271(61):949-58.

6. Reagan-Shaw S, Nihal M, Ahmad N. Dose translation from animal to human studies revisited. FASEBJ. 2008;22(3):659-61.

7. Lytvynenko A, Rieznichenko L, Sribna V, Stupchuk M, Grushka N, Shepel A, et. al. Functional status of 
reproductive system under treatment of silver nanoparticles in female mice. Int $\mathrm{J}$ Reprod Contracept Obstet Gynecol. 2017;6(5):1713-20.

8. Sribna V, Kaleynykova O, Grushka N, Blashkiv T, Voznesenska T, Yanchiy R. Resumption of meiotic maturation of oocytes, pre- and postimplantation mortality of embryos under ten-time intravenous treatment of silver nanoparticles in mice. Int $\mathrm{J}$ Reprod Contracept Obstet Gynecol. 2018;7(11):4360-5.

9. Zhang X, Liu Z, Shen W, Gurunathan S. Silver nanoparticles: synthesis, characterization, properties, applications, and therapeutic approaches. Int J Mol Sci. 2016;17(9):1534.

10. Khan U, Saleh T, Wahab A, Khan M, Khan D, Khan $\mathrm{W}$, et al. Nano-silver: new ageless and versatile biomedical therapeutic scaffold. Int $\mathrm{J}$ Nanomed. 2018;2(13):733-62.

11. Tiedemann D, Taylor U, Rehbock C, Jakobi J, Klein S, Kues W, et al. Reprotoxicity of gold, silver, and gold-silver alloy nanoparticles on mammalian gametes. Analyst. 2014;139(5):931-42.

12. Hsin Y, Chen C, Huang S, Shih T, Lai P, Chueh P. The apoptotic effect of nanosilver is mediated by a ROS- and JNK-dependent mechanism involving the mitochondrial pathway in NIH3T3 cells. Toxicol Lett. 2008;179(3):130-9.
13. Piao M, Kang K, Lee I, Kim H, Kim S, Choi J, et al. Silver nanoparticles induce oxidative cell damage in human liver cells through inhibition of reduced glutathione and induction of mitochondria-involved apoptosis. Toxicol Lett. 2011;201(1):92-100.

14. Kim S, Ryu D. Silver nanoparticle-induced oxidative stress, genotoxicity and apoptosis in cultured cells and animal tissues. J Appl Toxicol. 2013;33(2):7889.

15. Laban G, Nies L, Turco R, Bickham J, Sepúlveda M. The effects of silver nanoparticles on fathead minnow (Pimephalespromelas) embryos. Ecotoxicol. 2010;19(1):185-95.

16. Chernousova S, Epple M. Silver as antibacterial agent: ion, nanoparticle, and metal. Angew Chem Int Ed Engl. 2013;52(6):1636-53.

Cite this article as: Sribna VA, Kaleinikova ON, Kuziv YI, Anyk AAV, Karvatskiy IN, Voznesenskaya TY, et al. Effect of one-time dextran-polyacrylamide polymer matrixes treatment on female reproductive function. Int J Reprod Contracept Obstet Gynecol 2020;9:2317-22. 